https://helda.helsinki.fi

Early mass communication as a standardizing influence? The case of the Book of Common Prayer

\author{
Nevalainen, Terttu \\ de Gruyter \\ 2020-09-07
}

Nevalainen, T 2020 , Early mass communication as a standardizing influence? The case of the Book of Common Prayer . in L Wright (ed.), The Multilingual Origins of Standard English pÿ. Topics in English Linguistics [TiEL] , no. 107 , de Gruyter , Berlin , pp. 239266 . https://doi.org/10.1515/9783110

http://hdl.handle.net/10138/334018

https://doi.org/10.1515/9783110687545-009

acceptedVersion

Downloaded from Helda, University of Helsinki institutional repository.

This is an electronic reprint of the original article.

This reprint may differ from the original in pagination and typographic detail.

Please cite the original version. 
Terttu Nevalainen

\section{Early mass communication as a standardizing influence? The case of the Book of Common Prayer}

Together with the King James Version of the Bible and the works of Shakespeare, the Book of Common Prayer has been one of the three fundamental underpinnings of modern English. (Wikipedia)

\section{Introduction ${ }^{1}$}

The Early Modern period (1500-1700) represents a transition from a mostly oral to a semiliterate society. In the $16^{\text {th }}$ century, an overwhelming majority of the English people could not sign their names, let alone write (Cressy 1980: 175-177). In the course of the $17^{\text {th }}$ century, literacy rates increased especially among the higher social orders and in towns, notably in London, but a high degree of illiteracy prevailed much longer in rural areas, and among the lower social ranks and women in general. Despite being unable to write or having little use for this technical skill in their daily lives, many people had acquired some ability to read. Yet, although the available reading matter became more plentiful with time and contained popular literature such as almanacs, the only book people living in the countryside typically owned was the English Bible (Lancashire 2012: $642)^{2}$

In its different forms, religion exerted a major cultural influence on people's lives in Early Modern England. Since church attendance on Sunday and holy days was made compulsory by the Act of Uniformity first passed in 1549, "the entire churchgoing population ... heard, read, and repeated after the priest the English language of the Prayer Book, including substantial readings from the Bible, at least once a week" (Long 2007: 68). Part of the liturgical reform of the Reformation, the vernacular was substituted for the traditional Latin as the language of public worship and of the Bible in the early $16^{\text {th }}$ century.

\footnotetext{
${ }^{1}$ I would like to thank the two anonymous reviewers and the volume editor for their most useful and constructive feedback on the first version of this chapter.

${ }^{2}$ For further discussion and references, see e.g. Nevalainen \& Raumolin-Brunberg (2017: 34-35, 40-42).
} 
We may argue that, published in the Book of Common Prayer (BCP), the English liturgy represents mass communication par excellence, as it involves a "process by which a person, group of people, or large organization creates a message and transmits it through some type of medium to a large, anonymous, heterogeneous audience" (Pearce 2009: 623). In the case of the BCP, all these creator categories are responsible for producing the text: the church as an organization, the groups of compilers and revisers of the text, and the individual minister transmitting it to the congregation. The publication of the Book of Common Prayer was an innovation in the mid-16 $6^{\text {th }}$ century in that it brought together the various rites and services of the Church in a single book, as well as provided "a single order of public worship to be followed uniformly in churches throughout the country" (Brook 1965: 17). In proportion to its receivers, it emerges as one of the most representative texts, if not the most representative text, in the Early Modern English period (EModE).

The receiver-based model of text representativeness comes from Leech (2007), who discusses it in the context of the balance and representativeness of linguistic corpora. He writes:

I maintain that the representation of texts should be proportional not only to their initiators, but also to their receivers. After all, decoding as well as encoding is a linguistic activity. [...] I propose, therefore, that the basic unit to be counted in calculating the size of a given textual universe is not the text itself, but an initiator - text - receiver nexus, which we can call an atomic communicative event (ACE). When a radio programme is listened to by a million people, there is only one text, but a million ACEs. (Leech 2007: 138)

Continuing Leech's argument, we can say that without decoding there is no linguistic influence. The overarching research question addressed in this chapter is precisely that: to what extent is it possible to detect the impact of liturgical language on the mainstream usage of the period and, ultimately, on the English language at large, as suggested by the Wikipedia quote in the epigraph? More specifically, how can a linguist approach empirically the question of the direction of linguistic influence over time (a) from liturgical language to general usage and, vice versa, (b) from general usage to liturgical language? The first alternative is raised in the context of standardization and the consolidation of liturgical registers in the vernacular, but it is of course the second that must have provided the structural foundation for the use of English in liturgical functions in the first place.

These questions have been addressed in general terms in work that approaches language and religion as a sociolinguistic field of study. Beginning with language choice, Crystal (1990: 122) 
notes that "indeed, no imposed linguistic change has ever affected so many people at once as when Latin was replaced by the vernacular in Roman Catholic Christianity". A particular area of sociolinguistic interest is "the way in which the language of the sacred writings affects later forms of language" (Samarin 1987: 13). Enlarging on the impact of liturgical language on the vernacular, Darquennes and Vandenbussche (2011: 7) argue that "[i]t is commonly known that translations of holy scriptures triggered and influenced processes of standardization in many languages". The authors support their argument by referring to the contributions in Deumert and Vandenbussche (2003) on individual Germanic languages which discuss the standardizing influence of the Bible and liturgy on various levels of language ranging from spelling and lexis to morphology and syntax. Emanating from the religious domain, such standardizing changes diffuse from outside the speech community and represent, in sociolinguistic terms, change from above. By contrast, liturgical and biblical language following and being influenced by the current usage of the speech community would represent the opposite kind of process, change from below (see e.g. Labov 2007: 346; and for an application to Biblical Hebrew, Kim 2013: 89-94).

This chapter is organized as follows. Section 2 sets the scene by discussing the issue of alleged conservativeness of language use in the religious domain in the Early Modern period. The Book of Common Prayer and its sources and revisions are introduced in section 3. Section 4 approaches the research questions outlined above empirically by comparing a number of grammatical features in the two major Early Modern editions of the Book of Common Prayer published a hundred years apart. Section 5 returns to the influence of liturgical language as a form of mass communication, and the concluding remarks in section 6 assess the major findings of the study.

\section{The language of religion and "changing linguistic habits"}

In his discussion of the topic, Crystal (1990: 132) makes the broad generalization that "[I]iturgical language, as religious language generally, typically looks backwards, not forwards". He supports this statement by listing a number of grammatical and lexical features that until quite recently represented the liturgical linguistic norms in much of the English-speaking world. These include, for example, function words and inflections (thou, thee, ye, art, wilt, unto, -(e)th, -(e)st, spake, brethren, etc.), imperative or subjunctive verbs with the subject expressed (go thou, do we sit, 
glory be to the Father, praise be), as well as distinctive idioms (who livest and reignest, through the same Jesus Christ) (Crystal 1990: 122-123).

The features Crystal lists are characteristic of Early Modern English religious prose, and liturgical prose in particular, which is also traditionally described as conservative and resistant to linguistic innovation and change (e.g. Brook 1965: 107). Kohnen, Rütten and Marcoe (2011) acknowledge this generalization, but go on to show that that is not the case for all religious registers: in many respects, prayers, catechisms, sermons and religious biographies reflect changes in the language over time.

The situation is more intricate for the liturgical genres that are consciously modified over time. Although religious texts such as the 1611 King James Bible and the 1662 edition of the Book of Common Prayer may be characterized as linguistically conservative, this does not hold for their predecessors, early $16^{\text {th }}$-century Bible translations and the first editions of the Book of Common Prayer. Their translators and compilers were faced with a two-fold challenge: at the time, it was important to show that the vernacular was suitable for the Scriptures, but it was equally important to make the Bible and liturgical language understandable to the common people both at church and at home. This was the stated aim of William Tyndale (1494-1536), the first English translator of the New Testament from the Greek original, to whose work the subsequent Bible translations in the Early Modern period are heavily indebted (Barber 1997: 55-56, Lancashire 2012: 642).

In particular, morpho-syntactic features that were archaic in the $17^{\text {th }}$ century were not necessarily so a century before. These include such typical southern verbal forms as the third-person present indicative suffix - $(e)$ th (as opposed to $-(e) s$ ) and the present indicative plural be (as oppose to are). As to pronouns, the traditional subject form ye was current, as was the use of the relative pronoun which with human antecedents. In personal correspondence, for example, the forms $-(e) s$, are, and subject you, which all came to be generalized in the language, were still variable in the mid$16^{\text {th }}$ century, while ye and you had replaced the second person singular thou in most contexts (Nevalainen 2000, 2006). The following three examples (1-3) come from letters that John Johnson (b. 1514), a wool merchant active in the City of London and Calais, wrote to his wife in 1545 and 
which reveal a range of variation common at the time both at the individual level and at the level of the community at large. ${ }^{3}$

(1) Your yong jentleman, Mr. Prat, hathe complayned by his lettre to his mother that he lackythe bothe meat and drycke, as well his brekefastes, as also at meles not sufficient. (CEEC, John Johnson to Sabine Johnson, 1545; JOHNSON 250)

(2) All your menservauntes have bene of counsaill with hym, for they be of no les opynion, declaring that your breid is not good ynoghe for dogges, and drincke so evill that they cannot drinck it, but ar fayn when they go into the towne to drincke to their dynnars. (CEEC, John Johnson to Sabine Johnson, 1545; JOHNSON 250)

(3) Yf ye knowe they complayn with cawse, I praie you se it amendyd: (CEEC, John Johnson to Sabine Johnson, 1545; JOHNSON 250)

John Johnson uses the southern -(e)th variant in the third-person singular present indicative (1). His use of the indicative plural of be is variable, and he alternates between be and are in the same context (2). The interpretation of the second-person pronoun in (3) is ambiguous: if "I praie you" is parsed as a clausal unit, you is the object form, but if "you se it amended" is analysed as a clause, you becomes the subject form. Such ambiguous contexts may have contributed to the change from ye to you in the subject function at the time (Nevalainen \& Raumolin-Brunberg 2017: 60-61). The three linguistic variables illustrated in (1) - (3) were among those focused on by Kohnen, Rütten and Marcoe (2011), who found that the religious registers they studied adopted the incoming forms with time, although their rates of change varied. There were also features such as the second-person singular pronoun thou, characteristic of liturgical language, which persisted in these registers and continued to be used, for example, in prayers throughout the EModE period. Interestingly, the authors show (in their Figure 3) that an increasing proportion of all thou-forms in catechisms, sermons and religious biographies did not represent primary use but occurred in Bible quotations and addresses to God, in invocations or short prayers, inserted into the text.

In her comprehensive study of the BCP, Brook (1965) nevertheless maintains that the religious language of the BCP and the Bible is sui generis, adhering to its own standards:

\footnotetext{
${ }^{3}$ CEEC $=$ The Corpus of Early English Correspondence . Compiled by Terttu Nevalainen, Helena Raumolin-Brunberg; Samuli Kaislaniemi, Mikko Laitinen, Minna Nevala, Arja Nurmi, Minna Palander-Collin, Tanja Säily \& Anni Sairio, Department of Languages, University of Helsinki. http://www.helsinki.fi/varieng/CoRD/corpora/CEEC/. The letter collections included are listed with their references, e.g., in Nevalainen \& Raumolin-Brunberg (2017).
} 
The rough alternation between the issue of revised editions of the Book of Common Prayer and revised translations of the Bible may have helped to establish a standardised 'religious' usage, common to both books, kept alive by tradition in the face of changing linguistic habits. (Brook 1965: 107).

She suggests that this religious usage can be seen most clearly in the forms of verbs and pronouns. However, focusing on the BCP, "changing linguistic habits" were in fact given as one of the reasons that necessitated its 1662 revision (Figure 1). The question then becomes how far-reaching were these changes and what kinds of linguistic choices were made regarding ongoing linguistic change?

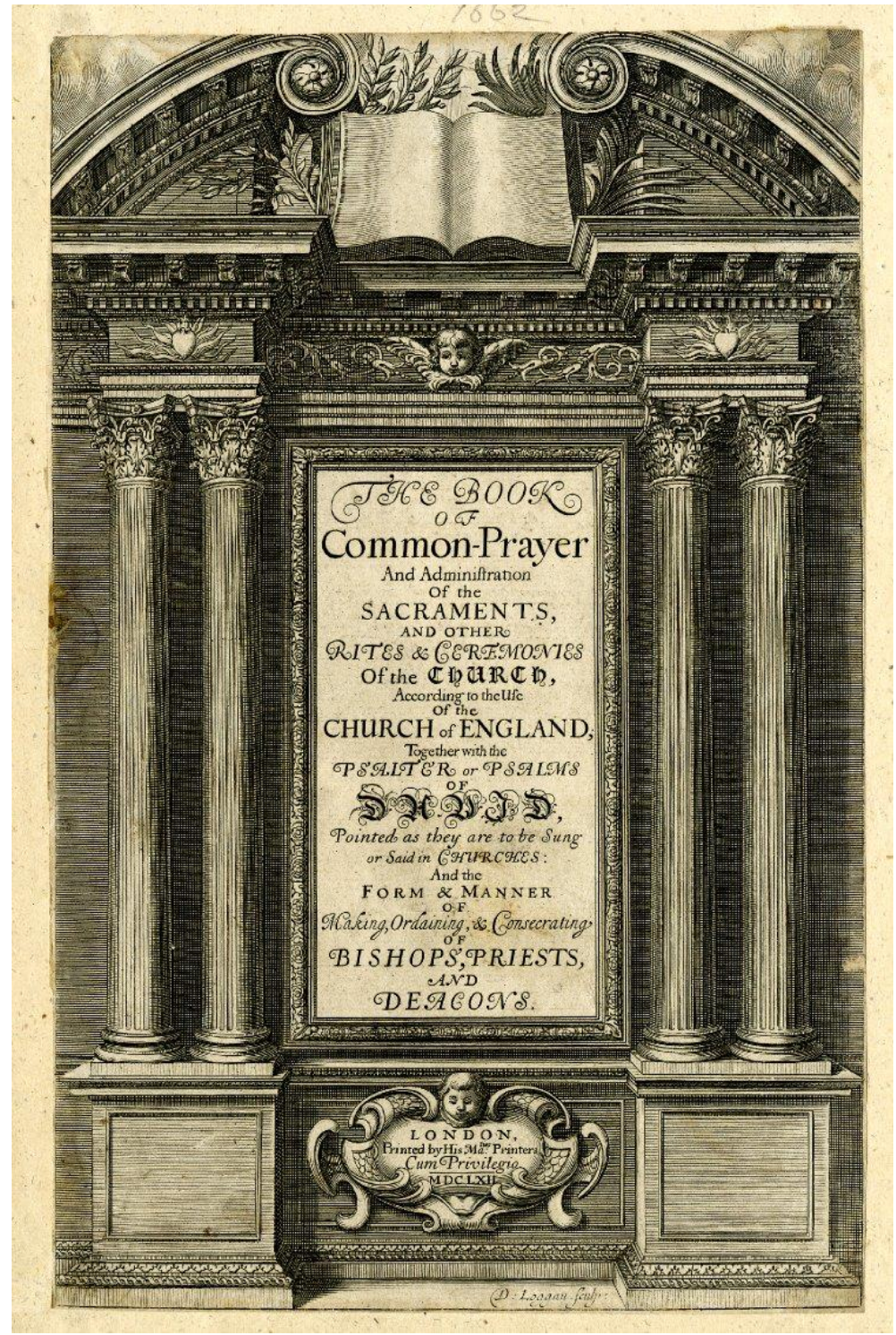

Figure 1. The 1662 Book of Common Prayer (Church of England; public domain, https://commons.wikimedia.org/w/index.php?curid=50893180). 


\section{The Book of Common Prayer: an overview}

\subsection{Brief history and popular reception}

The first edition of the Book of Common Prayer was published under Edward VI, England's first Protestant monarch, in 1549, and it was reissued with some doctrinal alterations in 1552 . This edition was enforced by the 1552 Act of Uniformity, only to be repealed the following year by Mary I, Edward's Catholic successor. The 1552 Book was reissued basically unaltered under Elizabeth I in 1559. The extract in (4) from a letter sent in 1574 by Bishop Parkhurst of Norwich to William Maister, his diocesan chancellor, details the hierarchical network of church officials involved in securing that the order of the Book of Common Prayer was duly observed in parishes.

(4) Mr. Chancelor, for the better execucion of the seruice comitted to vs by the justices toching the reformacion of such persons as shalbe found any waye to disobey the order of the booke for the forme of common prayer and admynistracion of the sacramentes, yt is thought verey necessarye that comandement be sent to my archdeacons and their mynisters that they and every of them in ther seuerall circuites do geue in chardge to the clergie and the questmen to present before them betwene this and the first weke in Lent, viz. before the first of March next, the names and surnames of all such persons as dwelling in their seuerall parishes be negligent, obstinate, or any other enemies or hinderers of her Majestie's procedinges, contrarye to the said boke and the statute prouided in that behalfe. (CEEC, John Parkhurst to William Maister, 1574; PARKHURST 226-227)

Some glimpses of the popular reception of the Book can be caught, for example, in ego documents such as diaries and personal correspondence. In a letter addressed to Sir Robert Cecil in 1601, Sir John Harington complains that he has not been offered the commission of colonel in the county of Somerset that he applied for because he was thought to be "backward in religion". In the extract in (5), Harington, a poet and courtier, appeals to his adherence to the Book of Common Prayer as proof to the contrary, and goes on to boast that he in fact has a better command of the Articles of the Creed and the Catechism than his young rival.

(5) I protest before god to yowr honor I ame no papist neyther in lyfe or thowght, I allow and use the book of common prayer, which many of owr forward men doe not, I beleeve 12 articles of the creed and they beleeve skant 11. and thowgh yt ys unusuall in Choyce of a Collonell to examin him by his Catachysme, yet yf I cannot geve accownt of both dutyes better then my ryvall can of eyther, let me loose all place and all good opinion. (CEEC, John Harington to Sir Robert Cecil, 1601; HARINGTON 88) 
During the Interregnum (1642-60) the Book of Common Prayer was banned, but it continued to be used by most churches. A new, revised edition of the Book was completed after the Restoration in 1661, enforced by and printed together with the Act of Uniformity in 1662 (see Figure 1). ${ }^{4}$

All the clergy had to accept this revised Prayer Book by St. Bartholomew's Day, 24 August 1662. Some dissenting reactions to it were recorded by Samuel Pepys in his diary, quoted in (6) and (7). ${ }^{5}$ Pepys himself steered a middle course in matters of religion, disliking both Puritan extremism and strongly authoritarian clergy, but observed most practices required of an Anglican: he attended his home parish "with a moderate regularity", said grace before and after meals and conducted Sunday prayers at home (Latham 1983: 351).

(6) He told me the new service-book (which is now lately come forth) was laid upon their deske at St. Sepulchre's for Mr. Gouge to read; but he laid it aside, and would not meddle with it: and I perceive the Presbyters do all prepare to give over all against Bartholomewtide. (10 August 1662)

(7) Among other things they tell me that there hath been a disturbance in a church in Friday Street; a great many young people knotting together and crying out "Porridge" ${ }^{6}$ often and seditiously in the church, and took the Common Prayer Book, they say, away; and, some say, did tear it; but it is a thing which appears to me very ominous. I pray God avert it. After supper home and to bed. (24 August 1662)

The Book of Common Prayer is estimated to have gone through over 500 editions and sold up to a million copies between 1549 and 1729 in English alone (Cummings 2011: x, Swift 2013: 32). As appears from Pepys's diary entry in (8), the Book was also published in French (as well as in Latin and Welsh), and in a large variety of print formats from folio to octavo, and in black letter and Roman type.

(8) At last I rose, and with Tom to the French Church at the Savoy, where I never was before a pretty place it is - and there they have the Common Prayer Book read in French, and, which I never saw before, the minister do[th] preach with his hat off, I suppose in further conformity with our Church. (28 September 1662)

\footnotetext{
${ }^{4}$ For further details, see e.g. Brightman (1921), Brook (1965), Cummings (2011), and Swift (2013). The Wikipedia article traces the history of the BCP to the present. https://en.wikipedia.org/wiki/Book_of_Common_Prayer\#1662.

${ }^{5}$ My quotes come from the online edition of The Diary of Samuel Pepys at https://www.pepysdiary.com/.

${ }^{6}$ A nickname given to the Prayer Book by the Dissenters.
} 
Swift (2013: 30 -31) remarks that the BCP was cheaper than the Bible, and specifies that, in 1549, a royal proclamation set its cost "at 2 shillings and 2 pence with no binding, 3 shillings and 3 pence bound in sheepskin, and 4 shillings in calves' leather"; by the end of the century its price had come down to about 10 pence - at the time people could buy a Shakespeare Quarto for a sixpence and the cheapest theatre ticket for a penny.

\subsection{Sources and revisions}

The principal author and compiler of the Edwardine Books of 1549 and 1552 was Archbishop Thomas Cranmer. With some revisions, the 1552 Book prevailed as the Anglican service book well into recent times: it was not until the late $20^{\text {th }}$ century that a complete revision of the Anglican service was approved and came into use.

Cranmer's original work entailed the substitution of the vernacular for the traditional Latin. There were several modes of compilation: translations, mainly from Latin; adaptations of vernacular and non-vernacular sources; and fresh compositions. Different styles were needed for oral delivery and reading, and the different components of the BCP. For example, when devising the vernacular form for the Collect, a short formulaic prayer that sets the theme for the occasion to be observed, Cranmer provided a powerful English model for the classical periodic construction (Adamson 1999: 590-591, Ferguson 1976: 102, Brook 1965: 128 -137, Prins 1933: xi-xiv; for further discussion, see section 5).

Cranmer translated Latin old rites into English, making adjustments befitting the requirements of the theology of the Reformation (Long 2007: 66). Swift (2013: 32-33) notes that the Book of Common Prayer was partly based on Cranmer's 1538 Latin breviary, which prescribed the daily prayers, psalms, and readings from the Bible, to be recited at canonical hours. It was modelled on an earlier breviary commissioned by Pope Paul III and written by the Spanish cardinal Francisco de Quinones. On the other hand, reformed continental influences, notably the Lutheran ritual, provided direct and indirect input into the first English BCP, for example, in the vernacular English Primers published in the $16^{\text {th }}$ century (Brook 1965: 18-19; for details, see Brightman 1921: Introduction). Brook (1965: 76-79) also discusses the impact on Cranmer of pre-Reformation works, including vernacular versions of the Lord's Prayer and Creed, and medieval vernacular books of devotion intended for private use. 
The single most significant subsequent revision of the Prayer Book was ultimately the work of a group of eight Anglican bishops. This solution was adopted when the conference summoned by the King in 1661 to discuss revision, consisting of bishops and Presbyterian clergy, had failed to reach an agreement (Brook 1965: 31 -32). As stated in the Preface to this edition, composed by Robert Sanderson, Bishop of Lincoln, one of the major aims of the undertaking was linguistic:

That most of the alterations were made [...] for the more proper expressing of some words or phrases of antient vsage, in terms more suteable to the language of the present times; and the clearer explanation of some other words and phrases that were either of doubtfull signification, or otherwise liable to misconstruction. (Preface to the 1662 BCP; Brightman 1921, vol. 2: 31-33)

Later critics maintain that this modernization project largely failed. Cummings (2011), for one, remarks that the 1662 edition was a consciously backward-looking book not only in its appearance - printed in black letter and preserving the ornamental initial letters of the early editions - but also linguistically. He argues that although some grammatical and lexical changes were made, "more often, with a linguistic historical consciousness that is remarkable, it preserved and even revelled in the archaic feel of an English language now a hundred years old" (Cummings 2011: xv). Similar linguistic conservatism is also attributed to the 1611 King James Bible, which provides the biblical material in the 1662 Book (Brook 1965: 106). Griffith-Jones (2013: 69) notes that the King James Bible was oddly archaic even in 1611; according to Crystal (2003: 59), some $80 \%$ of the text shows the influence of William Tyndale's early $16^{\text {th }}$-century translations.

Several initiatives for a new revision were made over the years. In 1689, Humphrey Prideaux, later the Dean of Norwich, pointed out the negative effects of linguistic change on the worship of God:

For the language in which it is wrote being constantly on fluxu [sic], as all other living languages are, in every age some words that were in use in the former grow obsolete, and some phrases and expressions formerly in grace and fashion, thorough disuse become uncouth and ridiculous, and always to continue these in our Liturgy without correction, would be to bring a disparagement upon the whole, and expose to contempt the worship of God among us. (Prideaux 1834: 52-53)

Prideaux's proposal was not acted upon, and the 1662 version prevailed. 


\section{Linguistic variation: a comparison of the 1552 and 1662 Books}

\subsection{Material}

The Wikipedia quotation at the beginning of this chapter refers to the many expressions going back to the Book of Common Prayer and allusions made to it that have left their mark on the use of the English language. Fewer claims have been made on the grammatical influence of the Book. There have been many reprints and reissues over the centuries, but any early grammatical impact on or indebtedness to the emerging mainstream usage can best be seen by comparing the two most influential EModE editions, those of 1552 and 1662.

As discussed in Nevalainen (2000), the diffusion of individual linguistic features into mainstream use can vary from a few decades, as with the subject form you, to some hundreds of years, as in the case of the indicative plural are. The linguistic alterations made to the 1662 edition of the BCP deviate from ordinary linguistic change in that they took effect immediately because they were implemented consciously on grounds that the existing expressions were no longer "suteable to the language of the present times". This situation makes it possible to observe the different kinds of change in highly stable environments.

For the purposes of this study, Brightman's parallel-text edition (1921) is used. Aiming at scholarly accuracy, it provides the sources and texts of the two editions analysed below. Brightman states: "throughout, I have endeavoured here to reproduce verbatim, litteratim and punctatim, and even with their misprints, the texts of the Whitchurche issues of the books of 1549 and 1552, and the text of the Book Annexed of 1661, omitting only the Psalter" (1921: Preface p. iv). The quantitative part of my study in sections 4.2 and 4.3, drawing on the analyses in Nevalainen (1987 and 1991), includes all the non-biblical matter shared by the two versions in Brightman's edition and subject to revision in $1661 .{ }^{7}$

My analysis divides the BCP material into two register categories, the Prefaces and Rubrics, on the one hand, and the Prayers and Orders of Service, on the other. As discussed by Brook (1965: 121-

\footnotetext{
${ }^{7}$ Stevenson (2006: 137-138) notes that "anyone wanting to know about the origins and development of the English Prayer Books and their many derivatives has to study Brightman", and specifies that, in Brightman, "it is also possible to see the many editorial changes made for the 1662 book". Marshall (1990) and some facsimiles available in the Early English Books Online (EEBO) collection were consulted for further information on the editions and their reissues. See https://eebo.chadwyck.com/home.
} 
$147,172-191)$, they are fundamentally different in that the Prefaces and Rubrics were intended to be read rather than to be spoken and heard, whereas the opposite was the case with the Prayers and Orders of Service. There is naturally a good deal of stylistic and register variation within these two major categories, but the basic distinction is crucial for trying to determine the language that reached the widest possible public at the time. It is therefore primarily the Prayers and Orders of Service that are the focus of interest in the following sections. Overall, the processes implemented in the 1662 Book can be divided into those aimed at consolidating register usage (4.2), and those representing linguistic modernization proper (4.3).

\subsection{Consolidating register usage}

The linguistic revision carried out in 1661 was not uniform across the BCP but it also maintained, enforced and, ultimately, created genre and register differences. This was achieved by a conscious retention or regularization of certain features that were current in the mid-16 ${ }^{\text {th }}$ century, bypassing any changes that they had undergone in general use by the mid-17 $17^{\text {th }}$ century. This aspect of the revision can therefore be thought of as a process of register harmonization from above rather than one of linguistic modernization from below. ${ }^{8}$

\subsubsection{Second-person pronouns thou and ye}

Register differences were maintained and consolidated in the 1662 Book by the retention, particularly in prayers, of the second-person singular pronoun thou with reference to the Deity (Barber 1997: 153-154, Brook 1965: 53-54). As noted in section 2, thou was consistently used in the corpus of Early Modern English prayers compiled by Kohnen, Rutten and Marcoe (2011), and it continued to appear to some extent with a singular referent especially in Bible quotations and prayer sections in the other religious genres they studied.

The use of thou and thee also sustained the second-person singular possessive determiners thy and thine, which in the early $16^{\text {th }}$ century were used much in the same way as the indefinite article in Present-day English still is: the long form precedes nouns that begin with a vowel and the short one those that begin with a consonant. The same pattern was followed by the determiners my and

\footnotetext{
8 in his sociolinguistic study of Biblical Hebrew, Kim (2013: 95) distinguishes between stylistic changes from above and natural and largely irreversible linguistic ones from below.
} 
mine. The extension of the short form to both prevocalic and preconsonantal contexts stabilized in personal correspondence by the end of the $16^{\text {th }}$ century (Nevalainen \& Raumolin-Brunberg 2017: $61-62)$. As illustrated by Brook (1965: 56), typical mid-16 ${ }^{\text {th }}$-century variability is shown by the two Edwardine Books, but the older usage was often adhered to in the 1662 version, as in (9) and (10).

(9) O Lord correct me, but with iudgement, not in thine anger, lest thou bring me to nothing. (1662, The Order for Morning Prayer, 129).

O Lord save thy people: and bless thine heritage. (1662, Mattins, 139)

Unlike the use of thou in prayers, the traditional subject form ye already varied with you in the 1552 book and its 1549 predecessor; in personal communication, the change to you ran its course in the $16^{\text {th }}$ century (Nevalainen \& Raumolin-Brunberg 2017: 60-61). Brook (1965: 55-56) finds that, in the 1549 and 1552 Books, the extension of you to the subject function occurs in the more conversational, less formally liturgical passages, for example, in the Exhortations at Baptism and in the Catechism, and that in most of these cases the 1662 Book reverts to the traditional subject form ye. The examples in (11) from the Communion illustrate this retrograde change being made hand in hand with modernization: the 1662 Book changes the southern indicative plural form be to are (see section 4.3.1) in a sentence where it consciously alters the incoming subject form of the 1552 Book, also accurately followed in its 1559 reissue, to ye.

(11a) When God calleth you, bee you not ashamed to saye you wyll not come? (1552, Communion)

(11b) When God calleth you, bee you not ashamed to saye you wyll not come? (1559, Communion $)^{9}$

(11c) When God calleth you, are ye not ashamed to say ye will not come? (1662, Communion)

The examples in (11) also illustrate another conservative feature that was largely retained in the 1662 Book: the third-person singular present indicative suffix -e(th) in calleth. In other religious genres the incoming - $(e) s$ is adopted later and more slowly than, for example, in personal letters this is the case especially in prayers and catechisms - but in none of the religious genres studied

\footnotetext{
${ }^{9}$ The booke of common praier, and administration of the sacramentes, and other rites and ceremonies in the Church of Englande. Londini in officina Richardi lugge, \& Iohannis Cawode, 1559. This version of the BCP, reissued under Queen Elizabeth in 1559, was essentially the same text as the 1552 Book.
} 
by Kohnen, Rutten and Marcoe (2011; Table 2) does the outgoing form prevail as the exclusive alternative.

\subsubsection{Affirmative periphrastic do}

The use of do periphrasis in affirmative statements presents an interesting case for the present study as major developments took place in general use between the publication of the two editions of the BCP. Affirmative periphrastic do picked up in the $16^{\text {th }}$ century and was popular in both emphatic and non-emphatic functions, and in formal as well as in informal contexts, but then underwent a rapid decline in the $17^{\text {th }}$ century (Nurmi 1999, Warner 2012). It was partly subject to revision in the 1662 Book but, besides omissions, there were also contexts to which the auxiliary was added (Nevalainen 1991).

The vast majority of the 116 instances of affirmative periphrastic do found in 1552 were retained in the 1662 Book, which returned altogether 114 occurrences. Eleven of the 1552 instances were deleted, and nine new ones added. All the additions were made to the Prayers and Orders of Service. The majority (seven out of nine) occurred with second-person singular subjects and in the past tense, as in (12).

(12) O Almighty God, who by thy blessed Son didst call Matthew from the receipt of custome to be an Apostle... (1662, Collects, Holy Days, 619)

However, this context did not automatically trigger the use of do. The case in (13), for example, adopts the earlier 1552 (and 1549) verb form unaltered.

Almighty God, who calledst Luke the Physician, whose praise is in the Gospel, to be an Evangelist... (1662, Collects, Holy Days, 625)

A notable difference between (12) and (13) is the material intervening between the subject (who) and the verb. It is one of the syntactic environments that often appears to have prompted the use of do. Comparing (14) and (15), we find that the deletion of do in (15) occurs in a context similar to (13), with no separation of the subject and the verb.

ALmightye God, whyche doest see that we haue no power of oure selues to helpe oure selues: (1552, Collect, Second Sunday in Lent, 299)

Almighty God, who seest that we have no power of our selves, to help our selves:

(1662, Collect, Second Sunday in Lent, 299) 
In four of the additions, a present perfect of the verb in the 1552 Book, as in (16), was replaced by a simple past tense form of $d o$ in the 1662 edition (17).

$$
\text { LOrd almightie, which hast indued thy holy Apostle Barnabas, with singuler giftes of }
$$
thy holy gost: (1552, Collect, Holy Days, 589)

O Lord God Almighty who didst endue thy holy Apostle Barnabas with singular gifts of the holy Ghost: (1662, Collect, Holy Days, 589)

In both Books, periphrastic do typically appears in a subordinate clause with a second-person singular subject and in the past tense. A typical context for both the retention and addition of do is the Collect. In general, the use of affirmative do is syntagmatically more marked than that of the simple finite verb in the Prayer Book.

Looking at the religious domain more broadly, Nevalainen (1990: 305, 313-316) found that the use of affirmative periphrastic do peaked in the early $17^{\text {th }}$ century both in the Bible extracts and sermon texts included in the Helsinki Corpus of English Texts (HC). These observations support Brook (1965: 110), who notes that periphrastic do is more common in the Authorized Version than in the Prayer Book. The study also shows that the use of do was on average more contextually constrained in the BCP than in the Bible extracts, where it in turn proved more constrained than in the sermon texts. As discussed above, in the 1662 Book, new instances of do were only added to heavily circumscribed contexts.

\subsection{Linguistic modernization}

\subsubsection{Indicative plural of be}

As shown above, the 1662 revision did not aim in every respect to present a rendition of the BCP in contemporary $17^{\text {th }}$-century English. However, there were some areas of grammar where this appears to have been the aim. One of them is the change of the traditional southern indicative plural form be to the originally northern form are, a process largely completed in the south by the turn of the $17^{\text {th }}$ century (Nevalainen 2000). The usage was still variable in the 1552 Book as, for example, in the identical contexts in (18). 
that be maried. [...] Heare also what sainct Peter thapostle of Chryste, which was hymselfe a maried man sayeth vnto all men that are maried. (1552, Matrimony, 813)

Table 1 compares the two editions showing the relative frequencies of these variant forms in the same non-biblical contexts but separating the Prefaces and Rubrics from the Prayers and Orders of Service. The use of the incoming form is quite evenly distributed in the 1552 Book in the two text categories analysed: it is found in about one third of the cases in both. In the 1662 edition are is the predominant form with an average $80 \%$ frequency but a small though statistically significant difference between the two text categories: are is introduced less frequently to the Prefaces and Rubrics than to the other non-biblical matter in the Book, i.e. the Prayers and Orders of Service.

Table 1. Distribution of be and are in the two editions according to text function.

\begin{tabular}{|c|c|c|c|c|c|}
\hline Text function & BCP 1552 & & Total N & ВCP 1662 & \\
\hline & are & be & & are & be \\
\hline Preface/Rubric & $16(35 \%)$ & $30 \quad(65 \%)$ & 46 (100\%) & 32 (70\%) & $14(30 \%)$ \\
\hline Prayer/Order of service & 36 (32\%) & $75 \quad(68 \%)$ & $111(100 \%)$ & 93 (84\%) & $18(16 \%)$ \\
\hline Total & 52 (33\%) & $105(67 \%)$ & $157(100 \%)$ & 125 (80\%) & 32 (20\%) \\
\hline
\end{tabular}

Example (11), above, shows how are is introduced into the Communion context in the 1662 Book, whereas example (19) illustrates the retention of be in a Preface. ${ }^{10}$

It is also more commodious; both for the shortness thereof, and for the plainness of the order, and for that the rules be few and easy. (1662, Preface, 37)

Certain linguistic contexts favour the use of are as opposed to be. In both Books, are is typically introduced to main clauses; in the 1662 edition, it always accompanies zero subjects, and it is strongly favoured in negative contexts and when the verb is used in the auxiliary function. The latter two features co-occur with are in the second subclause in (20), while be is found in the first, where the verb occurs as a copula in an affirmative clause (Nevalainen 1987: 308-310).

\footnotetext{
${ }^{10}$ The excerpt reproduces the Preface of the first Edwardine Book, which retained be in this context but also included are in the preceding context: "Rules are here set forth; which, as they are few in number, so they are plain, and easie to be understood"; these instances were replicated in the subsequent editions.
} 


\subsubsection{Subject relative pronouns which and who}

A comparison of the two BCP editions in examples (12) to (17) shows that the use of the relative pronoun which with reference to the Deity in 1552 had been changed to who in 1662 . There is a strong indication that the introduction of who as a subject relativizer was a Late Middle English innovation, which appeared in the closing formulas of English family letters in the $15^{\text {th }}$ century. Rydén (1983: 127) traces its first attestation back to a letter written by William Paston I in 1426 (see 21). ${ }^{11}$ Other early instances can also be found in the first half of the $15^{\text {th }}$ century, as in (22).

$$
\text { I submitte me and alle pis matier to yowr good discrecion, and euere gremercy God }
$$
and ye, who euere haue you and me in his gracious gouernaunce (William Paston I to William Worstede, John Longham, and Piers Shelton, 1426)

(22) I kan no more, but Almyzty God be owre good lorde, who have zow euer in kepyng. (CEEC, Agnes Paston to John Paston I, 1440s; PAston I,30)

Rydén further suggests that obvious models for the introduction of who into English in these contexts were letters written in French in the 14th and 15th centuries. Following the medieval principles of the art of letter-writing (ars dictaminis), letters and documents typically ended in a closing formula, with a relative clause appended to a word denoting the Deity (Nevalainen 2001). The examples in (23) and (24) come from the Stonor family letters, cited in Rydén (1983: 131). mais je pri a la Trinite qe vous doigne bone vie et sauntee de corps a long durre (Nicholas Cowley to Edmund Stonor, c. 1365) A dieu, qe vous garde (Margaret, Countess of Devon, to Edmund Stonor, c. 1380)

The letter-closing expressions also resemble Latin formulas at the end of late medieval sermons intended for delivery to lay audiences, as in (25) and (26) (Rydén 1983: 131). Rydén suggests that

\footnotetext{
${ }^{11}$ For further discussion on the rise of who, see e.g. Bately (1965), Romaine (1982), Fischer (1992: 300-301), Nevalainen \& Raumolin-Brunberg (2002), Bergs (2003), and Nevalainen (2012).
} 
these formulas with qui may have served as one model for the expressions found in English family letters. They would have been familiar to a large number of churchgoers.

To be whiche blisse brynge vs he pat for vs died on Rode Tre, qui cum Patre et Spiritu Sancto viuit et regnat (Ross 1940, sermon no. 14) pat we may com to pat place graunte vs he pat for vs died in Rode Tree. Amen. Qui cum Patre et Filio et Spiritu Sancto regnat, Deus per infinitatem (Ross 1940, sermon no. 37) A third likely source of influence were the native interrogative and generalizing $w h$-forms, which Bergs (2003: 105), for one, argues could have provided an easy extension of the relative paradigm to the subject relative function as well. These sources are also considered possible contributing factors by Nevalainen and Raumolin-Brunberg (2002: 111). The fact remains that the context in which the relative pronoun who begins to appear at any regularity is the closing formulas in English family letters in the $15^{\text {th }}$ century.

It is noteworthy, as Rydén (1983: 128-130) points out, that throughout the 15th century, the whforms which and the which were also available as alternative forms in English epistolary formulas, whereas the subject relative that apparently was not. The reason he suggests is that it could not be used in a non-restrictive function as required by the Deity formula.

It took some hundred years for anaphoric who to be established outside letter formulas and to diffuse from personal names to common nouns, and from non-restrictive to restrictive relative clauses. In the early $16^{\text {th }}$-century data, (the) which was still the majority wh-relativizer, whereas who only appeared in some $30 \%$ of the over 4,500 cases studied by Rydén (1966).

These findings are corroborated by the 1552 Book, where who also appears in about one third of the cases, and in nearly all of them in non-restrictive relative clauses (Table 2). The distribution of the two forms has become diametrically opposite in the 1662 Book, where the incoming who-form represents over $90 \%$ of the cases, and the use of which is largely confined to restrictive relative clauses. The 1662 Book changes which to who in practically all non-restrictive relative clauses, as for example in (29), below. For similar cases, see those in (12) to (17).

Table 2. Diffusion of who in the two editions of the BCP. 


\begin{tabular}{|l|c|c|c|c|c|}
\hline RC type & \multicolumn{2}{|l|}{ BCP 1552 } & Total N & BCP 1662 \\
\hline & who & which & & who & which \\
\hline Non-restrictive & $54(33 \%)$ & $109(67 \%)$ & 163 & $160(98 \%)$ & $3(2 \%)$ \\
\hline Restrictive & $2(9 \%)$ & $20(91 \%)$ & 22 & $12(55 \%)$ & $10(45 \%)$ \\
\hline Total & $56(30 \%)$ & $129(\mathbf{7 0 \%})$ & 185 & $172(93 \%)$ & $13(7 \%)$ \\
\hline
\end{tabular}

A typical context for which in the 1552 BCP is the invocation in the Collect, as in (27); this Collect also includes an instance of the minority form who with reference to the Deity in the formulaic ending. Both these relativizers correspond to the Latin qui in the Gregorian Rite in (28) and appear in non-restrictive relative clauses. A major difference between the two English pronouns is that which is used with a second-person antecedent, and who with a third-person one, exactly as in the letter-closing formulas in (21) and (22). This difference is taken as an indication that the diffusion of the subject relative who reversed the natural Noun Phrase Accessibility Hierarchy and was a conscious process (e.g. Romaine 1982: 212-213). God, which as vpon this daye hast taughte the heartes of thy faythfull people, by the sendinge to thē light of thy holy spirite: Graunte vs by the same spirite to haue a right iudgement in all thinges, \& euermore to reioyce in his holy comforte, through the merites of Christ lesu oure Sauioure: who lyueth and reygneth with thee in the vnitie of the same spirite, one GOD worlde wythout ende. (BCP 1552, Whitsunday, Collect, 443)

Deus qui hodierna die corda fidelium sancti spiritus illustratione docuisti: da nobis in eodem spiritu recta sapere et de eius semper consolatione gaudere. Per [dominum nostrum iesum christum filium tuum qui tecum viuit et regnat] in vnitate [eiusdem spiritus sancti deus per omnia secula seculorum.] (Sacramentarium Gregorianum 90; Brightman, 442)

God, who as at this time didst teach the hearts of thy faithfull people by the sending to them the light of thy holy spirit: Grant us by the same Spirit to have a right ludgement in all things, and evermore to reioyce in his holy comfort through the merits of Christ lesus our Saviour, who liveth and reigneth with thee in the Vnity of the same spirit, one God world without end. (BCP 1662, Whitsunday, Collect, 443) 
The distinction of Prefaces and Rubrics as opposed to Prayers and Orders of Service emerges with the relative pronouns as well: none of the seven instances of which with human antecedents in the Prefaces and Rubrics were changed in the 1662 edition; see (30).

(30) And every man which is to be admitted a Priest shall be full foure and twenty years old. (1662, Making of Deakons, Preface, 931)

However, who has the advantage of being confined to human antecedents, as opposed to which and that, which do not make the human/non-human distinction. In the second half $17^{\text {th }}$ of the century, the use of which with human antecedents had become extremely rare even in restrictive relative clauses in the language community at large (under 5\% of the cases; Ball 1996, Nevalainen 2012). Here the BCP usage is up to date if we exclude the Prefaces and Rubrics from the account.

\subsubsection{Inconspicuous innovation}

Certain grammatical features that underwent some revision in the $1662 \mathrm{BCP}$ have not attracted extensive long-term studies. A case in point is the distribution of the definite article. There were various "omissions" of the definite article in the early versions of the BCP, attributed to Latin influence by Brook (1965: 154-155), but which were subsequently supplied in the 1662 edition. However, it is difficult to distinguish any foreign influence from native constructions undergoing change at the time, including the use of a definite article determiner in a noun phrase consisting of an abstract noun complemented or modified by an of-phrase. ${ }^{12}$ The pattern is illustrated by the cases in (31) and (32). Here the source that the 1552 version was modelled on is more likely to be German (33) than Latin, in which case the zero article in (31) represents native English variation rather than direct Latin influence.

Almightie and euerlasting God, heauenly father, we geue thee humble thankes, that thou haste vouchsafed to call vs to [ $\varnothing$ ] knowledge of thy grace and fayth in thee. (1552, Public baptism, 733)

\footnotetext{
${ }^{12}$ For further discussion of early $16^{\text {th }}$-century usage, see Raumolin-Brunberg (1991: 173-185) and the references given there.
} 

thou hast vouchsafed to call vs to the knowledge of thy grace and faith in thee (1662, Public baptism, 733)

Source: Almechtiger Gott, himlische Vatter, wir sagen dir ewigs lob vnnd danck, das du vns zü dieser erkandnuss deiner gnaden vnd glauben an dich, so gnediglich berüffen hast. (Hermann of Cologne, Simplex ac pia deliberatio, p. 732)

\section{Discussion}

Discussing approaches to the effects of mass communication, Pearce (2009: 623-624) distinguishes three major paradigms. The first paradigm claims that mass media have a powerful, immediate and direct impact on their target audience, whereas the second, minimalist or limited effects paradigm, argues that mass media tend to reinforce existing behaviours rather than change them. Finally, the third paradigm presents the idea that the effects of mass communication are longterm and cumulative. It is the third approach that according to Pearce is generally supported today. Reinforced by weekly church attendance, the form and content of the Book of Common Prayer could no doubt exert all three kinds of effect depending on the circumstances but, over time, the effects have no doubt been long-term and cumulative. An important contributing factor, the spoken modalities of the liturgy contain essential elements of interpersonal communication, where the source and the receiver are individuals and the channel is face-to-face, although the communication itself is public and typically one-to-many rather than one-to-one (Crystal 1976, Pearce 2009: 623).

The use of the vernacular in liturgy became one of the cornerstones of the English Reformation. The Reformation period is also of linguistic consequence in that the social and economic changes that it brought about coincided with a population boom in London, which may have precipitated ongoing processes of linguistic change such as the rapid rise of the subject form you in the capital in the mid-16 ${ }^{\text {th }}$ century (Nevalainen 2000). However, besides changes in local norms, the period coincided with a supralocal competition of norms between traditional southern forms and some incoming originally northern ones, which collided in cases such as the verbal $-s$. The examples in (1) to (3) by the London merchant John Johnson suggest that the southern forms dominated in the 
1540s, and that the choices made by the compilers of the BCP largely followed the then-current southern practice. Comparing Johnson's usage with the members of his social network and the community at large shows that, apart from his conservative use of ye/you, he was linguistically a middle-of-the roader, neither particularly conservative nor progressive (Nevalainen \& RaumolinBrunberg 2017: 218-222). The same observation applies to many linguistic choices made in the 1552 Book of Common Prayer, including the variation between the subject forms ye and you (Brook 1965: 53ff.).

A similar comparison of the 1662 edition of the BCP shows a more varied picture. Bringing up to date the use of forms such as the subject relative pronoun who and the indicative plural are, which had been established outside the religious domain during the hundred years that separate the two editions of the $B C P$, the revisers fulfilled their promise to modernize the expression of the $B C P$. Certain other features that were no longer in current use at the time were nevertheless retained or even retroactively regularized. However, as shown by the empirical studies in section 4, this generalization needs to be qualified: the BCP consists of several subgenres and registers. Some of them, such as the Collects, originally translated and formulated by Cranmer, retain their specific linguistic features. The findings show, furthermore, that certain sections of the BCP, such as Prefaces and Rubrics, which were not intended for oral delivery, did not undergo a systematic modernization.

The inherent hybridity of the reformed liturgy complicates a direct answer to the question of the potential impact of the liturgical language on the general public and vice versa. One thing is clear: the changes made to the language of the $\mathrm{BCP}$, including the retroactive ones, helped consolidate the liturgical register status of these features and constructions. The modernization of certain expressions in 1662 may have contributed to the final stages of the codification of these forms as part of standard English, while the register characteristics and stylistic variability of liturgical language were in part maintained with forms and constructions no longer in general use (e.g. Griffith-Jones 2013: 81). For example, the second-person singular pronoun thou, accompanied by the verbal inflection in -(e)st, remained a hallmark of liturgical language for centuries. 
A good example of the slow process of modernization is the Collect. Ferguson (1976: 102-103) discusses its complex syntactic structure, which is encapsulated in the formula: Invocation (+ Basis) $>$ Petition (+ Purpose) + Ending. The Invocation was presented in the second-person singular, which could prompt the insertion of do for ease of pronunciation in the Basis, which was typically introduced by a relative clause (34).

O God, whych by the leadinge of a starre dyddest manyfeste thy onely begotten sonne to the Gentyles: Mercyfully graunt, that we which know thee now by fayth, may after this lyfe haue the fruicion of thy glorious Godhead, through Christ our Lorde. (1552, Collects, Epiphany, p. 249)

The 1662 Book modernized the relative pronoun but preserved the auxiliary do and inflected forms of thou. Although the perception of these linguistic features must have changed over the one hundred years that separates the two Books, there were segments of the population that in their daily life continued to use some of the archaic features found in the religious domain. These include the second person singular thou, which could be used in family correspondence by parents addressing their children or a husband addressing his wife well into the $18^{\text {th }}$ century. This was also the case with those members of the clergy who continued to use -th forms in verbs such as hath (for has) longer than members of other social groups. Examples such as these from Nevalainen et al. (2018) show that linguistic elements associated with liturgical language could continue life in general usage.

Returning to the Collect, it was not until the late $20^{\text {th }}$ century that both the structure and grammar were changed to better correspond to Present-day usage; lexical changes are also in evidence. The version in (35) comes from the American Book of Common Prayer for the Episcopal Church from 1979.

O God, by the leading of a star you manifested your only Son to the peoples of the earth: Lead us, who know you now by faith, to your presence, where we may see your glory face to face; through Jesus Christ our Lord, who lives and reigns with you and the Holy Spirit, one God, now and for ever. Amen. (Collects, Epiphany; Marshall 1990: 1979 II.) 
The late $20^{\text {th }}$-century revision of the Anglican service greatly reduced the distinctiveness of liturgical language. Crystal (1990) argues that in this context the discussion of language change ought to transcend the linguistic surface level and be defined at a deeper level of an aggregate of functions such as informative, identifying, expressive, performative, historical, etc. He sums up his argument by saying that "[a]lthough many of the low-level formal features of this variety have disappeared (the distinctive word-endings, grammatical words and so on), the major functional choices and contrasts in the language have been preserved and remain as distinctive as ever" (1990: 138).

\section{Conclusion}

The 1552 edition of the BCP represented the grammatical practice and linguistic variability of the language community in the mid-16 $16^{\text {th }}$ century, and this form of language provided the foundation for the Anglican liturgy for a long time to come. The linguistic modernization of the 1662 BCP was conservative, consolidating, for example, formulaic registers with grammatical elements such as thou and the concomitant use of affirmative periphrastic do. Reflecting the southern origins of biblical language, the third-person present indicative suffix $-(e)$ th was also preserved in the BCP. Among the features that underwent modernization, the southern present indicative plural be was mostly changed to the incoming are in the revision. This change had been completed in general use in the south earlier than that of verbal $-s$, and may therefore have been incorporated in the $17^{\text {th }}$-century revised edition more readily than the other verbal process.

Brook (1965: 34) summarizes the notion of 'Prayer-Book English' by saying that it is "a sixteenthcentury liturgical vernacular with a seventeenth-century overlay". During the one-hundred-year period that separates the two Books, the popular perception of the contemporaneity of the text must have changed accordingly. However, some of the distinct grammatical features of liturgical language also persisted into the $18^{\text {th }}$ century in literary and popular use. Although the BCP may not have exerted a formative standardizing influence on Early Modern English grammar at large, it made a long-term, cumulative impression on the register perception of the language community and so, in words of Cummings (2011: xv), came "to embody a site of deep social memory". 


\section{References}

Adamson, Sylvia (1999). Literary language. The Cambridge history of the English language, Vol. 3, 1476-1776, ed. by Roger Lass, 539-653. Cambridge: Cambridge University Press.

Ball, Catherine (1996). A diachronic study of relative markers in spoken and written English. Language Variation and Change 8: 227-258.

Barber, Charles (1997). Early Modern English. $2^{\text {nd }}$ ed. (1 ${ }^{\text {st }}$ ed. 1976.) Edinburgh: Edinburgh University Press.

Bately, Janet (1965). Who and which and the grammarians of the 17th century. English Studies 46: $245-250$.

Bergs, Alexander T. (2003). What if one man's lexicon were another man's syntax? A new approach to the history of relative who. Folia Linguistica Historica 24(1-2): 93-110.

Brightman, F. E. (1921) The English Rite, being a synopsis of the sources and revisions of The Book of Common Prayer. 2 vols. Second, revised edition. London: Rivingtons.

Brook, Stella (1965). The language of The Book of Common Prayer. London: Deutsch.

Cummings, Brian (2011). The book of common prayer: The texts of 1549, 1559, and 1662. Oxford: Oxford University Press.

CEEC $=$ Corpus of Early English Correspondence. 1998. Compiled by Terttu Nevalainen, Helena Raumolin-Brunberg; Jukka Keränen, Minna Nevala, Arja Nurmi \& Minna Palander-Collin. Helsinki: Department of English, University of Helsinki.

Cressy, David (1980). Literacy and social order. Cambridge: Cambridge University Press.

Crystal, David (1976). Nonsegmental phonology in religious modalities. Language in religious practice, ed. by William J. Samarin, 17-25. Rowley MA: Newbury House.

Crystal, David (1990). Liturgical language in a sociolinguistic perspective. Language and the worship of the church, ed. by David Jasper \& Ronald C. D. Jasper, 120-146. Basingstoke: Macmillan.

Crystal, David (2003). The Cambridge encyclopedia of the English language, 2nd ed. ( $3^{\text {rd }}$ ed. 2019). Cambridge: Cambridge University Press. 
Darquennes, Jeroen \& Wim Vandenbussche, eds. (2011). Language and religion as a sociolinguistic field of study: Some introductory notes. Sociolinguistica 25: 1-11.

Deumert, Ana \& Wim Vandenbussche, eds. (2003). Germanic standardizations: Past to present. Amsterdam \& Philadelphia: Benjamins.

Ferguson, Charles A. (1976). The collect as a form of discourse. Language in religious practice, ed. by William J. Samarin, $101-109$. Rowley MA: Newbury House.

Fischer, Olga (1992). Syntax. The Cambridge history of the English language, Vol. 2, ed. by Norman Blake, 207 -408. Cambridge: Cambridge University Press.

Griffith-Jones, Robin (2013). The King James Bible and the language of liturgy. The King James Version at 400: Assessing its genius as Bible translation and its literary influence, ed. by David G. Burke, John F. Kutsko \& Philip H. Towner, 69-86. Atlanta: Society of Biblical Literature.

Kim, Dong-Hyuk (2013). Early Biblical Hebrew, late Biblical Hebrew, and linguistic variability: A sociolinguistic dating of biblical texts. Leiden \& Boston: Brill.

Kingsford, Charles Lethbridge, ed. (1919). The Stonor letters and papers 1298-1483. Vols. I-II. Camden Society Third Series 29, 30. London: The Royal Historical Society.

Kohnen, Thomas, Tanja Rütten \& Ingvilt Marcoe (2011). Early Modern English religious prose - A conservative register? Methodological and Historical Dimensions of Corpus Linguistics (Studies in Variation, Contacts and Change in English 6), ed. by Paul Rayson, Sebastian Hoffmann \& Geoffrey Leech. Helsinki: VARIENG. http://www.helsinki.fi/varieng/series/volumes/06/kohnen_et_al/ Labov, William (2007). Transmission and diffusion. Language 83(2): 344-387.

Lancashire, Ian (2012). Early Modern English: Lexicon and semantics. English historical linguistics: An international handbook, Vol. 1, ed. by Alexander Bergs \& Laurel Brinton, 637-652. Berlin: De Gruyter Mouton.

Latham, Robert, ed. (1983). The Diary of Samuel Pepys, Vol. 10: Companion. Berkeley \& Los Angeles: University of California Press. 
Leech, Geoffrey (2007). New resources, or just better old ones? The Holy Grail of representativeness. Corpus Linguistics and the Web, ed. by Marianne Hundt, Nadja Nesselhauf \& Carolin Biewer, 133-149. Amsterdam: Rodopi.

Long, Lynne (2007). Vernacular Bibles and prayer books. The Oxford Handbook of English Literature and Theology, ed. by Andrew W. Hass, David Jasper \& Elisabeth Jay, 54-78. Oxford. Oxford University Press.

Marshall, Paul V. (1990). Prayer Book parallels: The public services of the Church arranged for comparative study (Anglican liturgy in America, Vol. 2). New York: The Church Hymnal Corporation.

Nevalainen, Terttu (1987). Change from above: A morphosyntactic comparison of two Early Modern English editions of The Book of Common Prayer. Neophilologica Fennica (Mémoires de la Société Néophilologique de Helsinki XLV), ed. by Leena Kahlas-Tarkka, 295-315. Helsinki: Société Néophilologique.

Nevalainen, Terttu (1991). Motivated archaism: The use of affirmative periphrastic do in Early Modern English liturgical prose. Historical English Syntax (Topics in English Linguistics 2), ed. by Dieter Kastovsky, 303-320. Berlin \& New York: Mouton de Gruyter.

Nevalainen, Terttu (2000). Processes of supralocalisation and the rise of Standard English in the Early Modern period. Generative theory and corpus studies: A dialogue from 10 ICEHL (Topics in English Linguistics 31), ed. by Ricardo Bermúdez-Otero, David Denison, Richard M. Hogg \& C.B. McCully, 329-371. Berlin and New York: Mouton de Gruyter.

Nevalainen, Terttu (2001). Continental conventions in early English correspondence. Towards a history of English as a history of genres (Anglistische Forschungen 298), ed. by Hans-Jürgen Diller \& Manfred Görlach, 203-224. Heidelberg: Universitätsverlag C. Winter.

Nevalainen, Terttu (2006). Mapping change in Tudor English. The Oxford history of English, ed. by Lynda Mugglestone, 178-211. Oxford: Oxford University Press.

Nevalainen, Terttu (2012). Reconstructing syntactic continuity and change in Early Modern English regional dialects: The case of who. Analysing older English, ed. by David Denison, Ricardo Bermúdez-Otero, Christopher McCully \& Emma Moore, with the assistance of Ayumi Miura, 159184. Cambridge: Cambridge University Press. 
Nevalainen, Terttu, Mikko Laitinen, Minna Nevala \& Arja Nurmi (2018). From nearing completion to completed. Patterns of change in 18th-century English: A sociolinguistic approach, ed. by Terttu Nevalainen, Minna Palander-Collin \& Tanja Säily, 251-254. Amsterdam \& Philadelphia: John Benjamins.

Nevalainen, Terttu \& Helena Raumolin-Brunberg (2002). The rise of the relative who in Early Modern English. Relativisation on the North Sea Littoral (LINCOM Studies in Language Typology 7) ed. by Patricia Poussa, 109-121. Muenchen: LINCOM Europa.

Nevalainen, Terttu \& Helena Raumolin-Brunberg (2017). Historical sociolinguistics: Language change in Tudor and Stuart England. $2^{\text {nd }}$ ed. London: Routledge.

Nurmi, Arja (1999). A social history of periphrastic do. Mémoires de la Société Néophilologique de Helsinki 56. Helsinki: Société Néophilologique.

Pearce, Kevin J. (2009). Media and mass communication theories. Encyclopedia of communication theory, ed. by Stephen W. Littlejohn \& Karen A. Foss, 623-627. Los Angeles, CA \& London, UK: SAGE Publications.

Prideaux, Humphrey ([1689] 1834). A letter to a Friend on the Convocation of 1689, recommending a revision of the Liturgy, ed. by Rev. C.N. Wodehouse. Norwich: John Stacy \& London: Longman, Rees, Orme, Brown, Green \& Longman.

Prins, A.A. (1933). The Booke of the Common Prayer, 1549: An enquiry into its language (phonology and accidence), with an introductory note about its composition and origin. Amsterdam: M. J. Portilelje.

Raumolin-Brunberg, Helena (1991). The noun phrase in early sixteenth-century English: A study based on Sir Thomas More's writings (Mémoires de la Société Néophilologique de Helsinki 50). Helsinki: Société Néophilologique.

Romaine, Suzanne (1982). Socio-historical linguistics: Its status and methodology. Cambridge: Cambridge University Press.

Ross, Woodburn O. (1940). Middle English sermons. Early English Text Society, O.S. 209. Oxford: Oxford University Press. 
Rydén, Mats (1966). Relative constructions in early sixteenth century English, Uppsala: Almqvist \& Wiksell.

Rydén, Mats (1983). The emergence of who as relativizer. Studia Linguistica 37(2): 126-134.

Samarin, William J. (1987). The language of religion. Sociolinguistics: An international handbook of the science of language and society, Vol. 1, ed. by Ulrich Ammon, Norbert Dittmar \& Klaus J. Mattheier, 85-91. Berlin \& New York: de Gruyter.

Stevenson, Kenneth (2006). The Prayer Book as 'sacred text'. The Oxford guide to the Book of Common Prayer: A worldwide survey, ed. by Charles Hefling \& Cynthia Shattuck, 133-139. Oxford \& New York: Oxford University Press.

Swift, Daniel (2013). Shakespeare's common prayers: The Book of Common Prayer and the Elizabethan age. Oxford: Oxford University Press.

Warner, Anthony (2012). Early Modern English: Periphrastic DO. English historical linguistics: An international handbook, Vol. 1, ed. by Alexander Bergs \& Laurel Brinton, 743-756. Berlin: De Gruyter Mouton. 